\title{
Entrepreneurial Orientation and Performance of Nigerian Banks: The Mediating Effect of Teamwork
}

\author{
Innocent Otache* \\ Othman Yeop Abdullah Graduate School of Business, Universiti Utara Malaysia, \\ Tradewinds 3D-115, 06010 Sintok, Kedah, Malaysia \\ Email: otache2@gmail.com \\ Rosli Mahmood \\ School of Business Management, College of Business, Universiti Utara Malaysia, \\ 06010 Sintok, Kedah, Malaysia, \\ Email: rosli@uum.edu.my
}

\section{Doi:10.5901/mjss.2015.v6n3p406}

\section{Abstract}

Business environment has become highly competitive, dynamic, and heterogenic. As a result, business organizations are expected to be entrepreneurially inclined. Also, for corporate entrepreneurial activities to have greater impact on organizational performance, organizational members (employees) must work collaboratively as a team. It is against this background that this study investigated the relationship between entrepreneurial orientation and performance of commercial banks in Nigeria and the mediating effect of teamwork on the relationship. Data were collected from 297 bank managers through a self reported questionnaire. SmartPLS-SEM was used to analyse the data collected and test the hypotheses formulated. The results of the structural model indicated a positive and significant relationship between entrepreneurial orientation and performance. Further evaluation of the structural model showed that teamwork fully mediated the relationship between entrepreneurial orientation and organizational performance. Based on the findings, it was concluded that while entrepreneurial orientation may be positively related to organizational performance, its impact on organizational performance will be greater if employees work collaboratively as a team.

Keywords: EO-performance relationship; entrepreneurial orientation; Nigerian banks; organizational performance; teamwork.

\section{Introduction}

The general field of entrepreneurship has been remarkably researched over the years. This might be because of the importance of entrepreneurship. Entrepreneurship plays a key role in nation building. Extant literature acknowledges entrepreneurship as the driving force that propels economic growth and development, and also creates job opportunities. Entrepreneurial activities are described as catalysts that speed up economic growth and development of an economy (Antoncic \& Hisrich, 2004; Kuratko, 2009). Similarly, entrepreneurial behaviours or activities are important to individuals as well as organizations for wealth creation and expansion.

Entrepreneurial activities contribute to the continued existence and growth of business organizations. Entrepreneurship is acknowledged as a key and distinguishing feature of successful business organizations today. Entrepreneurship scholars have posited that corporate entrepreneurial behaviour is needed for achieving increased profitability, higher market share, strategic renewals, innovativeness, and for achieving a sustainable competitive edge over competitors (Hornsby 2004). Business organizations need to display consistently creative and innovative behaviours for them to grow and succeed. In the light of resource-based view (RBV) theory, entrepreneurial orientation is regarded as an intangible organizational resource that gives an organization a competitive advantage, which, in turn, contributes to superior performance (Barney, 1991).

In this twenty-first century where business organizations compete globally, there is a need for them to behave entrepreneurially in order to flourish and have a competitive advantage over competitors in the ever-dynamic and highly competitive business environments (Kuratko, Morris, \& Covin, 2011; Kuratko, 2009). Generally, business environments have become highly hostile, unpredictable, and heterogenic (Kuratko, Ireland, \& Hornsby, 2004); it poses a lot of challenges to business organizations and managers. The business environments have become even more challenging 
considering the developments in the technological world today, particularly advancements in ICT. Advancements in technology have expanded the scope of competition among business organizations beyond their immediate territories. In order to cope with these challenges, business organizations need to become entrepreneurial and innovative in their activities, processes, and practices. Thus, it is either they behave entrepreneurially or they become outmoded (Kuratko, 2009). Entrepreneurial activities refresh and revitalize existing business organizations (Kuratko et al., 2004).

The relationship between entrepreneurial orientation and organizational performance has been studied considerably. Contrary to the proposition that entrepreneurial activities within existing organizations contribute to improved organizational performance, extant empirical findings show that the relationship between entrepreneurial orientation and organizational performance is unclear and inconclusive (Rauch, Wiklund, Lumpkin, \& Frese, 2009). Some researchers confirmed a positive relationship between entrepreneurial orientation and organizational performance (Arief, Thoyib, Sudiro, \& Rohman, 2013; Jia, Wang, Zhao, \& Yu, 2014; Karacaoglu, Bayrakdaroglu, \& San, 2012; Mahmood \& Wahid, 2012; Mokaya, 2012; Sharma \& Dave, 2011; Zhang \& Zhang, 2012). Others found a negative entrepreneurial orientation-performance relationship (Covin, Slevin, \& Schultz, 1994; George, Wood JR, \& Khan, 2001; Shamsuddin, Othman, \& Shahadan, 2012; Slater \& Narver, 2000).

Furthermore, some other researchers have argued that entrepreneurial orientation-performance relationship is not direct but depends on certain organizational and environmental variables like organizational culture, organizational structure, availability of organizational resources, competitive and dynamic environments, and top management support (Covin \& Slevin, 1991; Kuratko et al., 2004; Lumpkin \& Dess, 1996; Mohamad, Ramayah, \& Puspowarsito, 2011; Rutherford \& Holt, 2007; Wang, 2008; Wiklund \& Shepherd, 2005). Still, others have posited that entrepreneurial orientation needs to be combined with other business orientations such as market orientation, learning orientation, and employee orientation for organizations to achieve optimum performance (Grinstein, 2008; Idar \& Mahmood, 2011; Kwak, Jaju, Puzakova, \& Rocereto, 2013; Wang, 2008). Additionally, it is also argued that high entrepreneurial orientation does not guarantee continued improvement in organizational performance, especially in emerging economies for lack of institutional support, organizational formalization, and experienced managers (Tang, Tang, Marino, Zhang, \& Li, 2008; Tang \& Tang, 2010).

Considering the inconclusiveness and varied arguments about EO-performance relationship as discussed above, it can therefore be concluded that the relationship between entrepreneurial orientation and organizational performance is rather complex and needs to be examined by considering all possible related variables or factors that interact with organizational performance (Rauch et al., 2009). It is on this premise that teamwork is introduced in this study to play a mediating role in the relationship between entrepreneurial orientation and organizational performance. Contingency theorists posit that there must be congruence among important variables for an organization to achieve optimum performance (Lumpkin \& Dess, 1996; Rauch et al., 2009). While a lot of past studies have investigated both direct and indirect relationship between entrepreneurial orientation and organizational performance, there is no specific study, to the knowledge of the authors that has examined the mediating effect of teamwork on the relationship between entrepreneurial orientation and organizational performance - a gap this study fills. In this study, we put forward that entrepreneurial orientation passes through teamwork to affect organizational performance. By this, we mean that the more employees work cooperatively as a team, the more entrepreneurial an organization behaves. Besides, entrepreneurial and innovative ideas come from the employees (intrapreneurs), and the more these employees work together the better for the organization. An organization cannot be entrepreneurial without the employees behaving entrepreneurially and working collaboratively as a team (Ireland, Kuratko, \& Morris, 2006). Thus, we argue that the higher the team orientation among employees, the higher the entrepreneurial orientation and the more impact entrepreneurial orientation will have on organizational performance.

In view of the inconclusiveness regarding the relationship between entrepreneurial orientation and organizational performance as highlighted in the preceding paragraphs, the EO-performance relationship needs to be further studied. Thus, this study was set out to achieve the following objectives:

1) To determine whether entrepreneurial orientation is significantly related to organizational performance; and

2) To determine whether teamwork mediates the relationship between entrepreneurial orientation and organizational performance.

In order to achieve these objectives, the remainder of this paper is organized as follows. First, we review related literature on entrepreneurial orientation, teamwork, and organizational performance. Second, we discuss the methods adopted in carrying this study. Third, we present data analysis results. And lastly, we discuss the findings of this study and highlight the implications of the findings. 


\section{Literature Review and Hypotheses Development}

\subsection{Entrepreneurial Orientation (EO) and Organizational Performance}

Theoretically and empirically, entrepreneurial orientation is one of the constructs that has received a lot of attention over the years (Rauch et al., 2009). EO is a construct that captures corporate entrepreneurship or organizational-level entrepreneurship of existing organizations (Lumpkin \& Dess, 1996). It measures the entrepreneurial behaviour of an organization. Entrepreneurial orientation is a driving force that explains how entrepreneurial an organization behaves (Covin \& Wales, 2012). Entrepreneurial orientation is defined as the entrepreneurial behaviours of an organization as reflected in organizational activities, strategies, and processes (Lumpkin \& Dess, 1996). Miller (1983) defines entrepreneurial firm as one that takes risks, innovates, and is proactive. EO is also defined as one of the strategic orientations of an organization that describes the extent of entrepreneurial activities that is undertaken by the organization (Covin \& Wales, 2012). According to Pearce, Fritz, and Davis (2010), EO is defined as a set of behaviours that have the qualities of risk-taking, innovativeness, proactiveness, autonomy, and competitive aggressiveness (Covin \& Wales, 2012). It is also defined as a strategic orientation that an organization uses to adapt to changing business environment and have a sustainable competitive edge over rivals in the marketplace (Karacaoglu et al., 2012).

Entrepreneurial orientation is conceptualized and operationalized as a unidimensional as well as a multidimensional construct (Covin \& Wales, 2012). On the one hand, Miller (1983)/Covin and Slevin (1989) conceptualized and operationalized entrepreneurial orientation as a unidimensional construct with three dimensions: risktaking, innovativeness, and proactiveness. They argued that the three dimensions covary, which implies that an increase in one dimension leads to an increase in the other dimensions and vice versa. On the other hand, Lumpkin and Dess (1996) added two additional dimensions, namely autonomy and competitive aggressiveness, thereby bringing the dimensions of EO to five. Contrary to the position of Miller/Covin and Slevin that the dimensions of EO covary, Lumpkin and Dess argued that the dimensions of EO do not covary and that no dimension is stronger than the other. They concluded that the dimensions of EO independently vary with organizational performance, depending on how supportive environmental and organizational factors or variables are in their interactions with organizational performance (Covin \& Wales, 2012). The five dimensions of EO are briefly explained as follows.

a) Innovativeness: Innovativeness is the number one characteristic of an entrepreneurial organization (Kuratko et al., 2011). It is an act that sees creative ideas through, resulting in new products or processes. Schumpeter refers to innovation as the process of creatively destructing an "old order" in order to create a "new order" as a result of new combinations (Barringer \& Bluedorn, 1999; Lumpkin \& Dess, 1996). Innovative organizations see things the way others see them but do things differently. It is the ability to translate creative ideas into something concrete, unique, or novel. Innovation could be product-market innovation or technological innovation. Innovation could also be making strategic renewals or improvements to existing products, processes, or systems (Lassen, Gertsen, \& Riis, 2006). According to Schumpeter, innovative acts result in new products, markets, processes, sources of raw materials, and organizations (Kuratko, 2009; Lassen et al., 2006).

b) Risk-taking: It is the willingness and readiness to commit resources (own or borrowed) to pursue identified market opportunities that have a reasonable possibility of losses. Risk-taking, as an important feature of entrepreneurship, is not about taking extreme or uncontrollable risks, but it is about taking moderate and calculated risks. Risk-taking and innovativeness are related. This is because innovation involves risk-taking, and the higher an organization innovates, the more risks it takes (Kuratko et al., 2011).

c) Proactiveness: It is concerned with the ability of an organization to indentify or anticipate market opportunities and marshal out resources to exploit identified opportunities before other competitors notice the presence of such opportunities. It is about being the first or among the first organizations to spot the presence of market opportunities and exploit them. A proactive organization has the ability to see opportunities where others see none. An organization can be proactive by anticipating potential market needs and taking actions, in the form of delivering quality products, to meet the market needs. According to Miller (1987), proactive firms act on rather than react to their environments.

d) Autonomy: It is about giving a free hand to employees to explore and exploit identified market opportunities. Since creative and innovative ideas emanate from the people (the employees) (Ireland et al., 2006; Kuratko et al., 2011; Kuratko, 2009), therefore they should be allowed to experiment their creative and innovative ideas and bring them to fruition without being obstructed by the bureaucracies of the organization.

e) Competitive aggressiveness: It refers to different tactics or strategies that an organization uses to compete 
and outsmart competitors in the marketplace (Lumpkin \& Dess, 1996). It entails massive deployment of resources and vigorously pursuing market opportunities with a view to outshining rivals (Venkatraman, 1989).

Theoretically, entrepreneurship scholars have argued that entrepreneurial activities within existing business organizations are a source of rejuvenation that gives organizations competitive edges over rivals, which, in turn, contributes to enhanced organizational performance (Kuratko et al., 2004). Also, extant literature acknowledges that organizational-level entrepreneurship is related to profitability, growth, strategic renewal, market share, wealth creation, and overall performance (Antoncic \& Hisrich, 2004; Kuratko et al., 2004; Mohamad et al., 2011). As stated at the Introduction section, several empirical studies have examined the impact of entrepreneurial orientation (as a unidimensional and as a multidimensional construct) on organizational performance. However, available empirical findings regarding EO-performance relationship are mixed. Some studies found a positive EO-performance relationship (Arief et al., 2013) while others confirmed a negative EO-performance relationship (Slater \& Narver, 2000). Given the inconclusiveness and divergent arguments about EO-performance relationship, the EO-performance relationship needs to be further examined. Thus, the following hypothesis is developed.

H1 Entrepreneurial orientation is significantly related to organizational performance.

\subsection{Teamwork and Organizational Performance}

Synergistically, when people work together as a team the results they will achieve will be greater than the results they would have achieved if they had worked individually (Loyd, 2005; Xyrichis \& Ream, 2008). This is because team members share their knowledge and skills with one another, thereby resulting in efficient utilization of available resources and achievement of optimum results (Loyd, 2005). The importance of teamwork is mostly stressed in healthcare systems (Bitter, van Veen-Berkx, Gooszen, \& van Amelsvoort, 2013). It is also important in other organizations, especially organizations that deal with safety and high-risk environments (Bitter et al., 2013). Teamwork is so important that organizations are advised to organize around teams (Carlos, 2000). Teamwork is acknowledged as the characteristic of successful organizations today (Sohmen, 2013). Teamwork refers to behaviours displayed by a group of people working cooperatively to accomplish common goals (Loyd, 2005). It is the working together of a group of individuals in order to achieve common goals. Teamwork means that a group of people are working interdependently to accomplish common goals (Eldon, 2010). It is the ability of a group of individuals to work together to achieve a common vision. In business organizations, there might be no clearly defined teams; however, an atmosphere for teamwork among employees should be created, since all organizational members work towards the achievement of common organizational goals. An atmosphere for teamwork requires a common goal, shared commitment to organizational goals, results-oriented organizational structure, and collaborative climate.

A review of existing literature reveals that there is a dearth of empirical evidence of the positive relationship between teamwork and organizational performance measures such as profitability, market share, growth, and overall performance. However, there are evidences of a positive relationship between teamwork and other variables such as leadership, motivation, empowerment, and workers' productivity (Chen, 2010; Mattick \& Miller, 2006; Sewell, 2005; Sohmen, 2013). By implication, if teamwork is positively related to leadership, motivation, empowerment, and workers' productivity; and leadership, motivation, and workers' productivity are positively related to organizational performance measures such as profitability, market share, growth, and overall performance (Elena, 2010; Sokro, 2012; Yang, 2006); therefore, it can be concluded that teamwork is presumably related to organizational performance. In view of the significant role teamwork plays in the organization, its relationships with organizational performance and other organizational variables such as entrepreneurial orientation need to be empirically investigated. Therefore, the following hypothesis is formulated.

H2 Teamwork mediates the relationship between entrepreneurial orientation and organizational performance.

\section{Methods}

\subsection{Sample, data collection, and data analysis}

The sample of this study consisted of commercial banks in Nigeria and bank managers were chosen as key informants for their respective banks. The commercial banks seem to be firmly rooted and well organized compared to other categories of banks like the microfinance banks. To collect data for this study, a questionnaire was designed based on operationalization of latent variables examined. Thereafter, 1,000 copies of the questionnaire were mailed to the respondents (bank managers). In all, we received 322 questionnaires, accounting for approximately $32 \%$ response rate. 
A $30 \%$ response rate from a mailing system of administering questionnaire is acceptable (Sekaran \& Bougie, 2013). From the 322 questionnaires received, 297 usable questionnaires were selected for analysis. SPSS version 19 was used to test for non-response bias and normality of data. Results showed that there was no threat of non-response bias. Also, the normality test results showed that the data were normal as the $z$ kurtosis and $z$ skewness values were less than the recommended threshold of \pm 2.58 (.01 level of significance) (Hair, Black, Babin, \& Anderson, 2010). SmartPLS-SEM was used to analyse data and test the hypotheses formulated.

\subsection{Measurement of Latent Variables}

\subsubsection{Entrepreneurial Orientation}

In measuring entrepreneurial orientation of commercial banks in Nigeria, the position of Miller (1983)/Covin and Slevin (1989) was adopted. They operationalized EO as a unidimensional construct with three dimensions: risk-taking, innovativeness, and proactiveness. In all, nine reflective items were used to measure EO of Nigerian commercial banks as used by Mahmood and Wahid (2012).

\subsubsection{Teamwork}

To measure teamwork, we captured the perceived team orientation of employees of the banks. Five items were used to measure team orientation as a unidimensional latent variable and were adapted from Denison (1990) (Denison \& Neale, 1999). Note that both entrepreneurial orientation and teamwork were measured on a 5-point Likert scale, where "1" = "strongly disagree", "2" = "disagree", "3" = "undecided", "4" = "agree", and "5" = "strongly agree".

\subsubsection{Organizational Performance}

Organizational performance was measured subjectively with three items as a unidimensional latent variable. The three items were profitability, return on assets (ROA), and market share. Organizational performance measures were adapted from Antoncic and Hisrich, 2004. Note that the composite score of the three items were taken to represent organizational performance. Respondents (bank managers) were asked to assess the performance of their banks on average in the last three years on a 5-point Likert scale, where 1 = "very low", "2" = "low", "3" = "moderate", "4" = "high", and "5" = "very high".

\section{Results}

\subsection{Results of the Measurement Models}

Table 1 presents results of reflective measurement models evaluation. In all, the results of the measurement models showed that all the criteria or standards for assessing measurement models were met. The Cronbach's Alphas for all the latent variables were more than the recommended threshold of .70 (Hair, Hult, Ringle, \& Sarstedt, 2014; Hair, Black, Babin, \& Anderson, 2010). In addition, all the latent variables had composite reliability values greater than the recommended value of .70 (Fornnel \& Larcker, 1981; Hair et al., 2014). This revealed that the indicators measuring the latent variables were highly internally consistent. Equally, the average variance extracted values for all the latent variables were greater than the recommended value of .50 (Hair et al., 2014). This showed the unidimensionality and convergent validity of all the latent variables. Furthermore, all the latent variables passed the discriminant validity test (refer to Table 2). Also, the indicator loadings for all the items measuring each of the latent variables were greater than the recommended indicator loading of .70 (Hair et al., 2014).

Table 1. Results summary for the measurement models

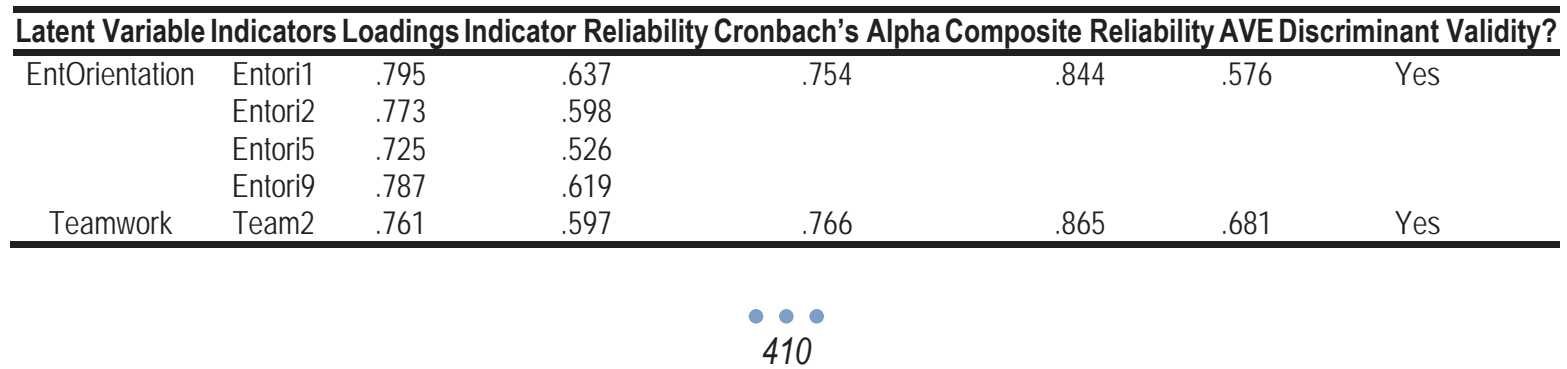




\begin{tabular}{lccccccc}
\hline & Team3 & .899 & .808 & & & & \\
\multirow{5}{*}{ Performance } & Team4 & .813 & .661 & .765 & .864 & .682 & Yes \\
& Perf1 & .860 & .740 & & & & \\
& Perf2 & .856 & .733 & .570 & & & \\
& Perf3 & .755 & .565 & & & \\
\hline
\end{tabular}

EntOrientation = entrepreneurial orientation

\subsection{Discriminant Validity and Square Roots of AVE}

Discriminant validity may be defined as the extent to which a latent variable is different from other latent variables (Hair, Hult, Ringle, \& Sarstedt, 2014; Hair, Black, Babin, \& Anderson, 2010). Discriminant validity shows that a latent variable is unique and measures some phenomena other latent variables do not capture. The average variance extracted (AVE) of a latent variable should be more than the highest correlation that the latent variable has with other latent variables for a discriminant validity test to be passed (Fornnel \& Larcker, 1981). An assessment of the average variance extracted for all the latent variables and the correlations between the latent variables showed that all the latent variables passed the discriminant validity test. The average variance extracted for each of the latent variables was greater than the highest correlation that the latent variable has with other latent variables. Table 2 shows results of the discriminant validity test performed.

Table 2. Discriminant validity and square roots of average variance extracted

\begin{tabular}{cccc}
\hline latent variables & Entrepreneurial orientation & Performance & Teamwork \\
\hline Entrepreneurial orientation & 0.759 & & \\
Performance & 0.203 & 0.825 & \\
Teamwork & 0.372 & 0.252 & 0.826 \\
\hline
\end{tabular}

Note. Numbers shown diagonally (in bold) are square roots of AVE and the remaining values are correlations between latent variables.

\subsection{Results of the Structural Model and Hypotheses Testing}

Table 3 presents results of the structural model. The table indicates the path coefficients (beta values) for all structural relationships tested in the models. Also, Figure 1 shows results of bootstrapping of the structural model.

Table 3. Path coefficients and hypotheses testing

\begin{tabular}{lcccc}
\hline Structural relationships & Path Coefficient & Std Errors & $T$ values & \multicolumn{1}{c}{$\boldsymbol{P}$ values } \\
\hline EntOrientation $\rightarrow$ Performance $^{\star * *}$ & .209 & .053 & 3.973 & $.000^{*}$ \\
EntOrientation $\rightarrow$ Performance $^{* \star *}$ & .127 & .066 & 1.918 & .055 \\
EntOrientation $\rightarrow$ Teamwork $_{\text {Teamwork } \rightarrow \text { Performance }}^{.372}$ & .205 & .049 & 7.540 & $.000^{*}$ \\
\hline
\end{tabular}

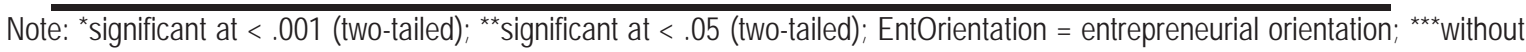
mediator variable; ${ }^{* \star * *}$ with mediator variable

Figure 1. Structural model showing the mediating effect of teamwork on the relationship between entrepreneurial orientation and performance

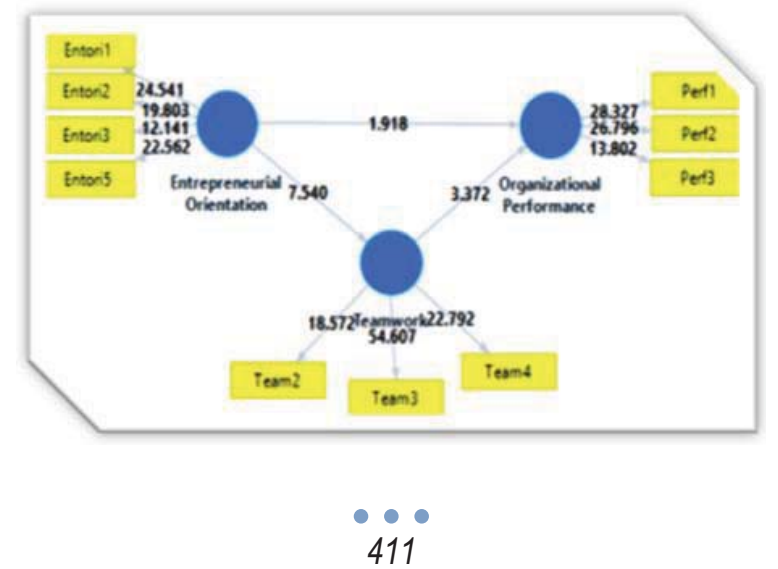


The results of the structural model indicated a positive and significant relationship between entrepreneurial orientation and organizational performance, $b=.209, t$ value $=3.973, p$ value $<.001$. Further analysis of the structural model showed a positive and significant relationship between teamwork and organizational performance, $b=.205, t$ value $=$ $3.372, p$ value $=.001$. The results also revealed that entrepreneurial orientation and teamwork were positively and significantly related, $b=.372, t$ value $=7.540, p$ value $<.001$.

To assess the mediating effect of teamwork on the relationship between entrepreneurial orientation and performance, the following steps were followed. First, the relationship between entrepreneurial orientation and performance was examined without the mediator variable (teamwork) in the model. The result was significant, $b=.209, t$ value $=3.973, p$ value $=.000$. Second, the mediator variable was added to the model and the results were assessed. From the results, the relationship between entrepreneurial orientation and performance became non-significant, $b=.127$, $t$ value $=1.918, p$ value $=.055$. This showed that teamwork fully meditated EO-performance relationship. For a full mediation to occur, the relationship between the independent variable and the dependent variable should not be significant with the presence of the mediator variable (Baron \& Kenny, 1986; Hair et al., 2010; Wu \& Zumbo, 2007). To further ascertain the significance of the mediating effect, a Sobel test was carried out. To perform a Sobel test, the beta values (path coefficients) together with their standard errors for the relationship between entrepreneurial orientation and teamwork, $b=.372$, standard error $=.049$ and for the relationship between teamwork and organizational performance, $b$ $=.205$, standard error $=.061$ were used. The results of the test showed that the mediating effect was significant, $t$ value= $3.0510, p$ value $=.0012$ (one-tailed), $p$ value $=.0025$ (two-tailed) .

\section{Discussions and Implications}

This study investigated the relationship between entrepreneurial orientation and performance of commercial banks in Nigeria and the mediating effect of teamwork on the relationship. As predicted, the results of the structural model revealed that entrepreneurial orientation and organizational were positively and significantly related. This finding is consistent with the findings of previous studies that examined the relationship between entrepreneurial orientation and organizational performance (Mahmood \& Wahid, 2012; Sharma \& Dave, 2011; Zhang \& Zhang, 2012). It means that the higher the entrepreneurial orientation, the greater the organizational performance. It also implies that entrepreneurial orientation is a predictor of organizational performance. Furthermore, as hypothesized, further assessment of the structural model indicated that teamwork fully mediated the relationship between entrepreneurial orientation and performance. Teamwork was positively and significantly related to entrepreneurial orientation and organizational performance. It means that the higher the team orientation, the higher the entrepreneurial orientation, and by extension, the greater the performance. The result of the analysis means that teamwork is an antecedent to both entrepreneurial orientation and organizational performance. It means that teamwork predicts both entrepreneurial orientation and organizational performance. More importantly, it means that teamwork has the ability to transfer the impact of entrepreneurial activities to organizational performance.

The findings of this study have some important managerial implications. First, the findings of this study underscore the importance of entrepreneurial activities within existing organizations. It implies that organizations must be entrepreneurial in their activities, processes, and operations. The findings suggest that organizations must behave entrepreneurially for them to achieve competitive edge over rivals and accomplish improved organizational performance. Second, the findings of this study confirm the key role that teamwork plays in organizations. The results of this study suggest that teamwork helps to explain the impact of entrepreneurial orientation on organizational performance. It has an insightful implication for organizations and managers. It implies that teamwork should be encouraged in organizations, as that is one of the significant ways to achieve optimal organizational performance. The implication is that the more teamoriented employees are, the more entrepreneurial the organization behaves. Entrepreneurial ideas emanate from the employees (intrapreneurs). Therefore, their creativity and innovativeness should be properly harnessed by creating the atmosphere for teamwork to thrive. Team spirit should be encouraged among employees.

Additionally, the findings also have some theoretical implications. To the knowledge of the authors, this study is the first to investigate the mediating role of teamwork in the relationship between entrepreneurial orientation and organizational performance. By providing empirical evidence of the mediating role played by teamwork in entrepreneurial orientation-performance relationship, this study adds to the existing knowledge on the field of corporate entrepreneurship. It provides a clearer understanding of the relationship between corporate entrepreneurship and organizational performance. Overall, the findings confirm the applicability and generalizabilty of contingency and resource-based view theories. Based on the findings of this study, it was concluded that while entrepreneurial orientation may be positively related to organizational performance, its impact on organizational performance will be greater if employees work 
collaboratively as a team.

\section{References}

Antoncic, B., \& Hisrich, R. D. (2004). Corporate entrepreneurship contingencies and organizational wealth creation. Journal of Management Development, 23(6), 518-550. doi:10.1108/02621710410541114

Arief, M., Thoyib, A., Sudiro, A., \& Rohman, F. (2013). The effect of entrepreneurial orientation on the firm performance through strategic flexibility: A study on the SMEs cluster in Malang. Journal of Management Research, 5(3), 44-63. doi:10.5296/jmr.v5i3.3339

Barney, J. (1991). Firm resources and sustained competitive advantage. Journal of Management, 17(1), 99-120. Retrieved from http://jom.sagepub.com/content/17/1/99.short

Baron, R. M., \& Kenny, D. A. (1986). The moderator-mediator variable distinction in social psychological research: Conceptual, strategic, and statistical considerations. Journal of Personality and Social Psychology, 51(6), 1173-82. Retrieved from http://www.ncbi.nlm.nih.gov/pubmed/3806354

Barringer, B. R., \& Bluedorn, A. C. (1999). The relationship between corporate entrepreneurship and strategic management. Strategic Management Journal, 444, 421-444.

Bitter, J., van Veen-Berkx, E., Gooszen, H. G., \& van Amelsvoort, P. (2013). Multidisciplinary teamwork is an important issue to healthcare professionals. Team Performance Management: An International Journal, 19(5/6), 263-278. doi:10.1108/TPM-112012-0041

Carlos, G. (2000). Leadership, teamwork, and empowerment: Future management trends. Cost Engineering, 42(10), $41-44$.

Chen, C.-C. (2010). Leadership and teamwork paradigms: Two models for baseball coaches. Social Behavior and Personality: An International Journal, 38(10), 1367-1376. doi:10.2224/sbp.2010.38.10.1367

Covin, J. G., \& Slevin, D. P. (1989). Strategic management of small firms in hostile and benign environments. Strategic Management Journal, 10(March), 75-87.

Covin, J. G., \& Slevin, D. P. (1991). A conceptual model of entrepreneurship as firm behaviour. Entrepreneurship Theory and Practice, $16(1), 7-25$.

Covin, J. G., Slevin, D. P., \& Schultz, R. L. (1994). Implementing strategic missions: Effective strategic, structural and tactical choices. Journal of Management Studies, 31(4), 481-505.

Covin, J. G., \& Wales, W. J. (2012). The measurement of entrepreneurial orientation. Entrepreneurship Theory and Practice, 36(4), 677702. doi:10.1111/j.1540-6520.2010.00432.x

Denison, D. R., \& Neale, W. S. (1999). Denison organizational culture durvey facilitator guide (pp. 1-30).

Eldon, R. (2010). Making the team: Teams, teamwork, and teambuilding. Chemical Engineering Progress, 106(6), 41-45.

Elena, N. I. (2010). Human resources motivation - An important factor in the development of business performance. Economic Science Series, 21(1), 1039-1046.

Fornnel, C., \& Larcker, D. F. (1981). Evaluating structural equation models with unobservable variables and measurement error. Journal of Marketing Research, 18(1), 39-50.

George, G., Wood JR, R. D., \& Khan, R. (2001). Networking strategy of boards: Implications for small and medium-sized enterprises. Entrepreneurship \& Regional Development, 13(1), 269-286. doi:10.1080/0898562011005811

Grinstein, A. (2008). The relationships between market orientation and alternative strategic orientations: A meta-analysis. European Journal of Marketing, 42(1/2), 115-134. doi:10.1108/03090560810840934

Hair, J. F., Black, W. C., Babin, B. J., \& Anderson, R. E. (2010). Multivariate analysis: A global perspective. US: Pearson Education, Inc.

Hair, J. F., Hult, G. T. M., Ringle, C. M., \& Sarstedt, M. (2014). A primer on partial least squares structural equation modeling (PLSSEM). California: SAGE Publications, Inc.

Idar, R., \& Mahmood, R. (2011). Entrepreneurial and marketing orientation relationship to performance: The SME perspective. Interdiscilplinary Review of Economics and Management, 1(2), 1-8.

Ireland, R. D., Kuratko, D. F., \& Morris, M. H. (2006). A health audit for corporate entrepreneurship: Innovation at all levels: Part I. Journal of Business Strategy, 27(1), 10-17. doi:10.1108/02756660610640137

Jia, J., Wang, S., Zhao, X., \& Yu, X. (2014). Exploring the relationship between entrepreneurial orientation and corporate performance: The role of competency of executives in entrepreneurial-oriented corporations. Nankai Business Review International, 5(3), 326344.

Karacaoglu, K., Bayrakdaroglu, A., \& San, F. B. (2012). The impact of corporate entrepreneurship on firms' financial performance: Evidence from Istanbul stock exchange firms. International Business Research, 6(1), 163-176. doi:10.5539/ibr.v6n1p163

Kuratko, D. F. (2009). Introduction to entrepreneurship. Canada: South-Western Cengage Learning.

Kuratko, D. F., Ireland, R. D., \& Hornsby, J. S. (2004). Corporate entrepreneurship behaviour among managers: A review of theory, research, and practice. Advances in Entrepreneurship, Firm Emergence and Growth, 7(04), 7-45.

Kuratko, D. F., Morris, M. H., \& Covin, J. G. (2011). Corporate innovation \& entrepreneurship. Canada: South-Western Cengage Learning.

Kwak, H., Jaju, A., Puzakova, M., \& Rocereto, J. F. (2013). The connubial relationship between market orientation and entrepreneurial orientation. The Journal of Marketing Theory and Practice, 21(2), 141-162. doi:10.2753/MTP1069-6679210202

Lassen, A. H., Gertsen, F., \& Riis, J. O. (2006). The nexus of corporate entrepreneurship and radical innovation. Creativity and Innovation Management, 15(4), 359-372. doi:10.1111/j.1467-8691.2006.00406.x 
Loyd, N. L. (2005). The impact of a teamwork environment on job satisfaction: A study of college and unniversity student affairs administrators. Unpublished doctoral thesis submmited to University of Virginia Charlottesville, Virginia.

Lumpkin, G. T., \& Dess, G. G. (1996). Clarifying the entrepreneurial orientation construct and linking it to performance. Academy of Management Journal, 21(1), 135-172.

Mahmood, R., \& Wahid, R. A. (2012). Applying corporate entrepreneurship to bank performance in Malaysia. Journal of Global Entrepreneurship, 3(1), 68-82.

Mattick, B., \& Miller, D. G. (2006). Teamwork pays. The Journal for Quality \& Participation, 30-33.

Miller, D. (1983). The correlates of entrepreneurship in three types of firms. Management Science, 29(7), 770-791.

Miller, D. (1987). Strategy making and structure: Analysis and implications for performance. Academy of Management Journal, 30(1), 732. doi:10.2307/255893

Mohamad, O., Ramayah, T., \& Puspowarsito, H. (2011). Corporate entrepreneurship and firm performance: The role of business environment as a moderator. The IUP Journal of Management Research, X(3), 7-27.

Mokaya, S. O. (2012). Corporate entrepreneurship and organizational performance: Theoretical perspectives, approaches and outcomes. International Journal of Arts and Commerce, 1(4), 133-143.

Rauch, A., Wiklund, J., Lumpkin, G. T., \& Frese, M. (2009). Entrepreneurial orientation and business performance: An assessment of past research and suggestions for the future. Entrepreneurship Theory and Practice, 33(3), 761-787. doi:10.1111/j.15406520.2009.00308.x

Rutherford, M. W., \& Holt, D. T. (2007). Corporate entrepreneurship: An empirical look at the innovativeness dimension and its antecedents. Journal of Organizational Change Management, 20(3), 429-446. doi:10.1108/09534810710740227

Sekaran, U., \& Bougie, R. (2013). Research methods for business: A skill-building approach. United Kingdom: John Willey \& Sons Ltd.

Sewell, G. (2005). Doing what comes naturally? Why we need a practical ethics of teamwork. The International Journal of Human Resource Management, 16(2), 202-219.

Shamsuddin, S., Othman, J., \& Shahadan, M. A. (2012). The dimensions of corporate entrepreneurship and the performance of established organization. ACRN Journal of Entrepreneurship Perspectives, 1(2), 111-131.

Sharma, A., \& Dave, S. (2011). Entrepreneurial orientation: Performance level. Journal of Indian Management, 8(4), 43-53.

Slater, S. F., \& Narver, J. C. (2000). The positive effect of a market orientation on business profitability: A balanced replication. Journal of Business Research, 48, 69-73.

Sohmen, V. S. (2013). Leadership and teamwork: Two sides of the same coin. Journal of IT and Economic Development, 4(2), 1-18.

Sokro, E. (2012). Analysis of the relationship that exists between organisational culture, motivation and performance. Problems of Management in the 21st Century, 3(2012), 106-119.

Tang, J., Tang, Z., Marino, L. D., Zhang, Y., \& Li, Q. (2008). Exploring an inverted u-shape relationship between entrepreneurial orientation and performance in Chinese ventures. Entrepreneurship Theory and Practice, 32(1), 219-239.

Tang, Z., \& Tang, J. (2010). Entrepreneurial orientation and SME performance in China's changing environment: The moderating effects of strategies. Asia Pacific Journal of Management, 29(12), 409-431. doi:10.1007/s10490-010-9200-1

Venkatraman, N. (1989). Strategic orientation of business enterprise: The construct, dimensionality, and measurement. Management Science, 35(8), 942-962.

Wang, C. L. (2008). Entrepreneurial orientation, learning orientation, and firm performance. Entrepreneurship Theory and Practice, $44(0), 635-657$.

Wiklund, J., \& Shepherd, D. (2005). Entrepreneurial orientation and small business performance: A configurational approach. Journal of Business Venturing, 20(1), 71-91. doi:10.1016/j.jbusvent.2004.01.001

Wu, A. D., \& Zumbo, B. D. (2007). Understanding and using mediators and moderators. Social Indicators Research, 87(3), 367-392. doi:10.1007/s11205-007-9143-1

Xyrichis, A., \& Ream, E. (2008). Teamwork: A concept analysis. Journal of Advanced Nursing, 61(2), 232-41. doi:10.1111/j.13652648.2007.04496.x

Yang, C. (2006). The Effect of Leadership and Entrepreneurial Orientation of Small and Medium Enterprises on Business Performance in Taiwan.

Zhang, Y., \& Zhang, X. (2012). The effect of entrepreneurial orientation on business performance: A role of network capabilities in China. Journal of Chinese Entrepreneurship, 4(2), 132-142. doi:10.1108/17561391211242744 